Reprod. Nutr. Dévelop., 1987, 27 (5), 945-953.

\title{
Neonatal changes in plasma cortisol, free and total iodothyronine levels in control and hypotrophic lambs
}

\author{
Chantal WRUTNIAK, G. CABELLO
}

Laboratoire des Maladies métaboliques, I.N.R.A. Theix, 63122 Ceyrat, France

Summary. Neonatal changes in plasma free and total iodothyronines, cortisol, glucose and urea levels have been studied in 8 control (birthweight $\geq 2.5 \mathrm{~kg}$ ) and 16 hypotrophic lambs (birthweight $<2.5 \mathrm{~kg}$ ) receiving limited amounts of colostrum during the first $36 \mathrm{~h}$ of life and then fed ad libitum.

During the period of colostrum feeding, plasma glucose levels were low in both groups and increased after the onset of ad libitum feeding; they were significantly lower in hypotrophic animals from birth to $36 \mathrm{~h}$.

Plasma urea levels increased during the period of colostrum feeding and decreased thereafter in all animals. At birth, they were significantly higher in hypotrophic lambs.

Over the entire period studied ( $20 \mathrm{~d}$ ), plasma levels of total T4, free T4, total T3 and free T3 were markedly lowered in hypotrophic lambs without alterations in the values of the T3/free T4 ratio. No differences could be observed in plasma reverse T3 and cortisol levels. For all blood parameters recorded, the neonatal changes were parallel in the two groups of lambs.

In agreement with hypoglycemia and hyperuremia observed at birth in hypotrophic lambs, with the litter size recorded for each experimental group and with previous results, placental insufficiency linked to a large litter size gestation could be at the origin of low thyroid hormone levels.

\section{Introduction.}

Depressed plasma thyroid hormone levels have been reported in small for gestational age (SGA) infants during the first days of life (Brock-Jacobsen et al., 1977 ; Erenberg, 1978 ; Uhrmann et al., 1978 ; Dussault et al., 1979 ; Sakaguchi et al., 1983). Moreover, positive relationships have been observed between birthweight and plasma triiodothyronine and/or thyroxine levels in newborn rats and lambs (Cabello and Levieux, 1980, 1981 ; Wrutniak and Cabello, 1983).

However, the origin, duration and clinical significance of thyroid hormone deficiency linked to neonatal hypotrophy are not well understood. Therefore, in order to gather information on that topic we studied the changes in plasma cortisol, free and total iodothyronine levels in control or hypotrophic lambs during the first $20 \mathrm{~d}$ of life. In addition, plasma glucose and urea levels were monitored to assess the nutritional status of the animals. 


\section{Material and methods.}

Animals. - Twenty-four Limousin $\times$ Romanov lambs born spontaneously between 142 and $145 \mathrm{~d}$ of gestation were used. Two groups were constitued on the following basis :

- control lambs ( $\mathrm{n}=8$ ): birthweight $\geq 2,5 \mathrm{~kg}$; the mean litter size and birthweight were $1.6 \pm 0.2$ and $3.11 \pm 0.12 \mathrm{~kg}$, respectively and the length of gestation, $143.4 \pm 0.9 \mathrm{~d}$;

- hypotrophic lambs ( $n=16$ ) : birthweight $<2.5 \mathrm{~kg}$; the mean litter size and birthweight were respectively $2.9 \pm 0.3$ and $1.88 \pm 0.08 \mathrm{~kg}(P<0.025$ and $P<$ 0.001 with controls) ; the length of gestation was $144.1 \pm 1.1$ days (N S with controls).

The allotment into the two experimental groups was made on the basis of studies conducted by Theriez et al. (1976) and Houssin and Brelurut (1980) showing that the mortality rate dramatically rose in newborn lambs when the birthweight was lower than $2.5 \mathrm{~kg}$. In Infants, rats and lambs, suckling could affect plasma thyroid hormone levels (Stbrak et al., 1978 ; Koldovsky et al., 1980 ; Wrutniak and Cabello, 1987a) ; moreover, milk ingestion was generally lower in hypotrophic than in control lambs; therefore, all the animals were removed from mothers and received limited amounts of a bovine colostrum pool in order to limit this variability $(2.5 \mathrm{~g} / 100 \mathrm{~g}$ birthweight $4,8,12,16,20,24,28$ and $32 \mathrm{~h}$ post-partum and thereafter artificial milk ad libitum).

Blood sampling. - Blood samples were collected into heparinized test tubes from a jugular vein. Plasma was separated by centrifugation within $15 \mathrm{~min}$ and kept frozen at $-20^{\circ} \mathrm{C}$ until analysis. Two $\mathrm{ml}$ blood samples were taken from each lamb at birth and every $4 \mathrm{~h}$ up to $36 \mathrm{~h}$, they were then taken subsequently 2,5, 10,15 and $20 \mathrm{~d}$ post-partum at 9 a.m.

Analytical and statistical methods. - All hormones were measured by radioimmunoassay as previously described (Cabello and Levieux, 1980 ; Wrutniak and Cabello, 1985 ; Wrutniak et al., 1985). Plasma glucose and urea levels were measured colorimetrically according to Bergmeyer et al. (1974) and Moore and Sax (1965) respectively.

Means are given with the standard error. The paired t-test was used to determine changes in the same group of lambs, whereas Student's t-test was used to assess differences between the two groups of lambs.

\section{Results.}

The mortality rate observed in this experiment was significantly higher in hypotrophic $(9 / 16)$ than in control lambs $(1 / 8, P<0.005)$.

Plasma glucose and urea leve/s (fig. 1). - At birth, plasma glucose levels were very low ; they remained constant during the period of colostrum feeding in control lambs, but decreased significantly from birth to to $20 \mathrm{~h}$ in hypotrophic animals $(P<0.025)$. After the onset of ad libitum feeding, plasma glucose levels 
rose until day 5 in the two experimental groups $(P<0.001)$. They were significantly lower in hypotrophic than in control lambs from birth to $36 \mathrm{~h}(\mathrm{P}<0.05$ to $P<0.001$ ).

At birth, plasma urea levels were higher in hypotrophic than in control animals $(P<0.05)$ and increased sharply in both groups during the period of colostrum feeding ( $P<0.001)$. After the onset of ad libitum feeding, they decreased significantly until day 5 (controls, $P<0.001$ ) or 10 (hypotrophic, $P<0.005$ ).
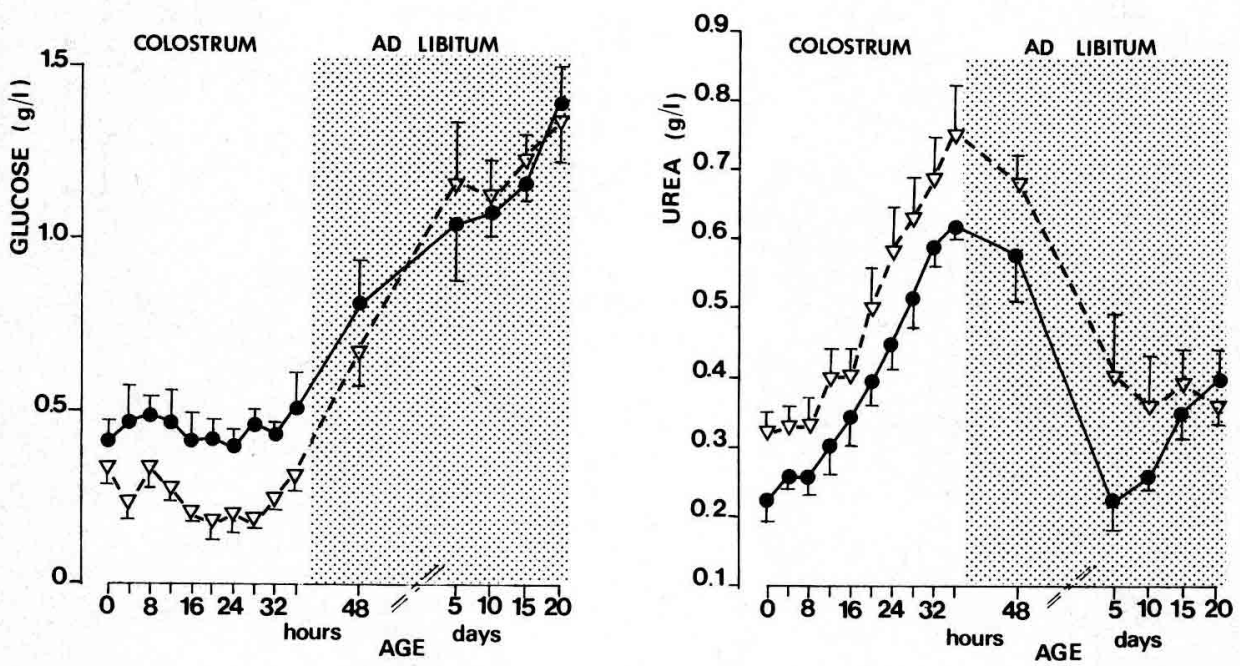

FIG. 1. - Neonatal changes in plasma glucose and urea levels in control (๑-) and hypotrophic lambs $(\nabla-\cdots---\nabla)$.

Plasma cortisol and iodothyronine levels (fig. 2). - High at birth, plasma cortisol levels decreased until day 20 ; however, a transient rise occurred between 4 and $8 \mathrm{~h}$ post-partum in both groups of lambs (controls : $\mathrm{P}<0.005$; hypotrophic lambs : $P<0.001)$. No significant difference could be observed between the two experimental groups throughout the period studied.

During the first $4-8 \mathrm{~h}$ of life, plasma T3 (controls : $\mathrm{P}<0.025$; hypotrophic : $\mathrm{P}<0.001$ ), free T3 (controls : $\mathrm{P}<0.05 ;$ hypotrophic : $\mathrm{P}<0.005$ ) and free T4 (controls : $\mathrm{P}<0.025$; hypotrophic : $\mathrm{P}<0.005$ ) rose significantly in both groups of animals. However, plasma total T4 levels increased over the same period in hypotrophic lambs $(P<0.01)$, whereas they did not change in the controls.

In control lambs, plasma levels of total $T 4(P<0.025)$, free $T 4(P<0.05)$ and total T3 $(\mathrm{P}<0.001)$ decreased sharply from 8 to $16 \mathrm{~h}$ post-partum. The same changes appeared in hypotrophic animals between 8 and $20 \mathrm{~h}$ after birth $(\mathrm{P}<$ $0.001, P<0.005, P<0.001$, respectively). Plasma free $T 3$ levels decreased from 8 to $20 \mathrm{~h}$ post-partum in both groups of lambs $(P<0.001)$. All the levels of these iodothyronines rose thereafter. Simultaneously, plasma reverse T3 levels increa- 

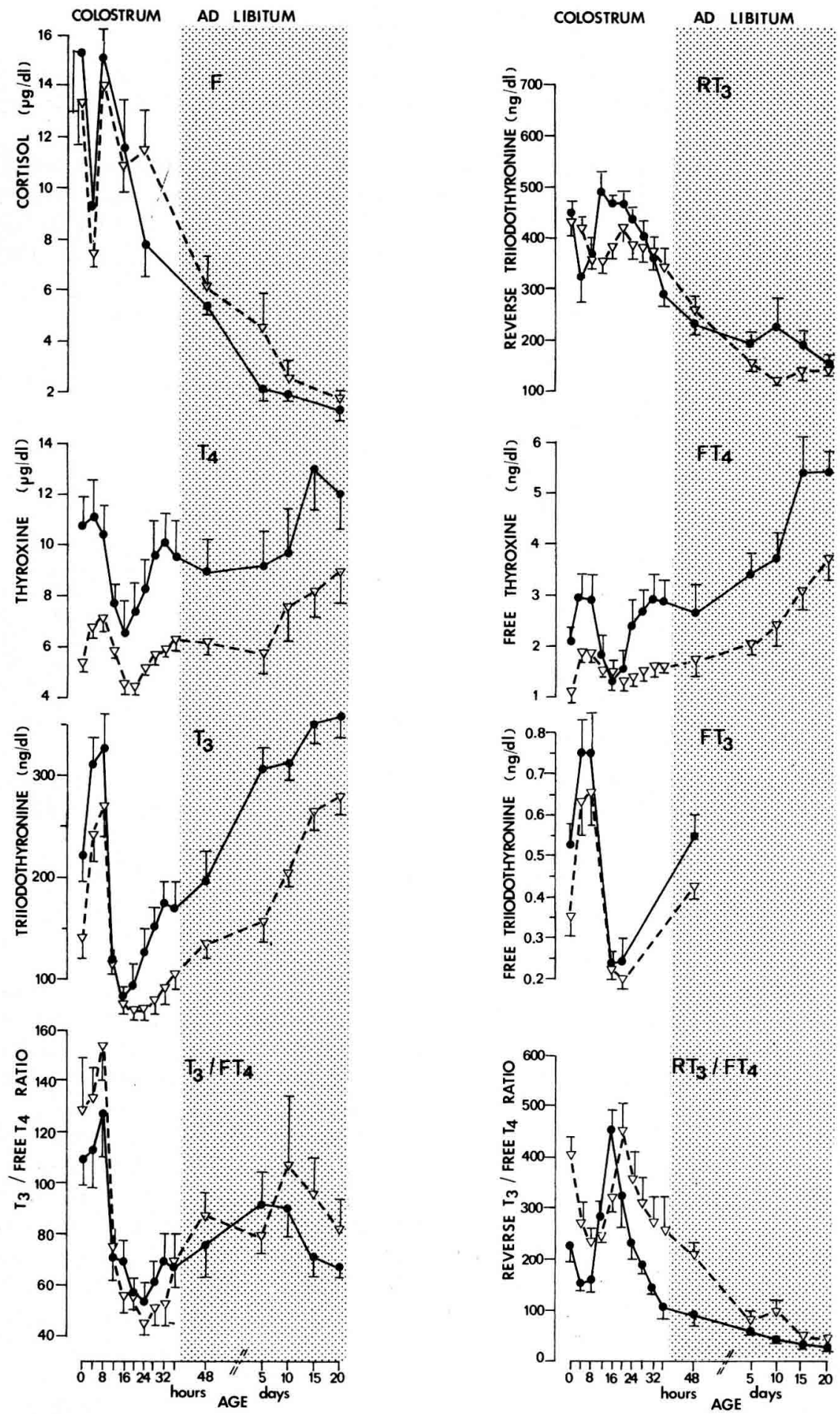

FIG. 2. - Neonatal changes in plasma cortisol and total and free iodothyronines levels in control $(\longrightarrow)$ and in hypotrophic lambs $(\nabla-\cdots-\cdots)$. 
sed between 4 and 12 (controls : $P<0.025$ ) or 12 and $20 \mathrm{~h}$ after birth (hypotrophic : $\mathrm{P}<0.011$; then they decreased until day 20 in all animals.

Throughout the entire period studied, plasma levels of total T4 were significantly depressed in hypotrophic animals $(P<0.025$ to $P<0.001)$; the same was true for plasma levels of free $T 4$, total $T 3$ and free $T 3(P<0.025$ to $P<0.001)$, with the exception of the $12.20 \mathrm{~h}$ period. The values of the $T 3 /$ free $\mathrm{T} 4$ ratio were unaffected, whereas those of the reverse $T 3 /$ free $T 4$ ratio were elevated at birth $(P<0.001), 48 \mathrm{~h}$ and 20 days post-partum $(\mathrm{P}<0.01)$. No clearcut differences could be drawn from the reverse $T 3$ levels.

\section{Discussion.}

Milk ingestion in suckling lambs amounted to $40 \%$ of the birthweight during the first $48 \mathrm{~h}$ of life (Shubber et al., 1979). As this spontaneous ingestion was much larger than the quantity of colostrum given to our lambs $(20 \%$ of the birthweight), it is not surprising that neonatal changes in plasma glucose, urea, cortisol and iodothyronines levels recorded in this experiment were similar that observed in food restricted lambs in previous works (Wrutniak, 1985; Wrutniak and Cabello, 1987a); in particular, during the first $36 \mathrm{~h}$ of life, plasma glucose levels were low and urea levels rose; a sharp decrease in plasma T4 and T3 levels occurred after $8 \mathrm{~h}$ post-partum whereas plasma reverse T3 and cortisol concentrations increased transiently.

However, from birth to $36 \mathrm{~h}$ post-partum, plasma glucose levels were lower in hypotrophic than in control lambs. This could be partly explained by a depressed food digestibility (Houssin and Davicco, 1979) and probably by higher energy needs linked to a greater sensitivity to neonatal cooling as observed by Alexander (1974) or, in the hypotrophic piglet, by Berbigier and Dussuel (1977); the decrease in glucose levels observed between birth and $28 \mathrm{~h}$ is in agreement with the latter hypothesis. The hypoglycemia and hyperuremia observed at birth in these animals argue in favour of the occurrence of fetal undernutrition, probably induced by placental insufficiency due to a large litter size gestation, as previously suggested (Cabello and Levieux, 1981).

In contrast to previous results (Cabello and Levieux, 1981), plasma cortisol levels were not affected by hypotrophy; however, the mean litter size differed strongly between the two experiments : 4 vs 2.9 in the present work; therefore it is possible to assume that very large litter sizes $(>3$ ) could be associated to hypercortisolemia due to stressful conditions.

As in the newborn SGA infant (Brock-Jacobsen et al., 1977 ; Erenberg, 1978 ; Uhrmann et al., 1978 ; Dussault et al., 1979 ; Sakaguchi et al., 1983), plasma levels of total T4 and T3 but also of free T4 and T3 were markedly depressed in hypotrophic lambs; this suggests that the lower levels of carrier proteins reported in the SGA baby by Brock-Jacobsen et al. (1979) are not an explanation for this phenomenon. Moreover, in contrast to the results reported in human newborns (Brock-Jacobsen et al., 1977) the values of the T3/free T4 ratio were not altered by hypotrophy, suggesting that at least in the lamb, this condition did 
no affect the peripheral T4 to T3 conversion. No significant differences could be observed in reverse T3 levels; however, the values of the reverse T3/free T4 ratio were higher in hypotrophic than in control lambs, suggesting a higher T4 to reverse T3 conversion, and/or a lower reverse T3 metabolic clearence rate.

In this experiment, plasma TSH levels were not monitored. However, recent data of our laboratory (Wrutniak and Cabello, 1987b) give evidence that they were not affected by hypotrophy in the lamb. Therefore, the iodinated hormone deficiency reported in this work cannot be considered as a classical hypothyroidism. Work is in progress to identify the nature of this phenomenon.

At this step of the discussion, these results raise a question : do the factors leading to poor intra-uterine growth also lower plasrna thyroid hormone levels ? or, is the thyroid hormone deficiency observed at birth (but probably occurring during the fetal life) the cause of a poor fetal growth ?

In agreement with the hyperuremia and hypoglycemia observed at birth, placental insufficiency in late gestation might explain the lowered plasma levels of active iodothyronine in hypotrophic lambs, at least during the first hours of life : - in sheep, hypotrophic newborns generally comes from large litters, as observed in the present experiment ; such pregnancies are associated with a marked reduction in placental exchanges between the mother and each fetus (Alexander, 1978) ;

- such a reduction obtained by ligating the maternal uterine vein and artery induces a depression in plasma fetal and neonatal T4 levels in the rat (Wrutniak and Cabello, 1983).

Moreover, low T4 and T3 levels are probably not at the origin of intra-uterine growth retardation :

- thyroid function only moderately affects fetal growth in sheep ; total thyroidectomy is associated with a $30 \%$ reduction of the birthweight (Hopkins and Thorburn, 1972) significantly lower than the spontaneous reduction observed in our hypotrophic lambs (about $40 \%$ ) with detectable amounts of iodinated hormones ;

- after reduction of mother-fetuse exchanges in the rat, fetal growth retardation occurred before and not after plasma T4 depression (Wrutniak and Cabello, 1983).

However, a moderate reverse effect of depressed thyroid hormone levels (induced by placental insufficiency) on fetal growth cannot be excluded.

In addition, we showed that not only the total, but also the free fraction of thyroid hormones are severely depressed over a long period in hypotrophic lambs. Since perinatal iodinated hormones increase pulmonary surfactant (Erenberg et al., 1979 ; Cunningham et al., 1980 ; Nwosu et al., 1980), intestinal maturation (Yeh et Moog, 1975, 1979 ; Cabello et al., 1984), markedly influences thermoregulation (Cabello, 1983 ; Wrutniak and Cabello, 1986), and in young ruminants reduces intestinal E. coli adhesion (Cabello et al., 1983, 1984), the thyroid hormone deficiency observed in this experiment could partly explain the high mortality rate recorved in hypotrophic lambs and underlined in the present work. 
Acknowledgements. - The authors thank Mrs Christiane Foucher and Mr P. Chagnaud for their technical assistance, and Mrs Marylee Rambaud for revision of the manuscript.

Résumé. Evolution néonatale des concentrations plasmatiques de cortisol et d'iodothyronines totales et libres chez l'agneau témoin ou hypotrophique.

L'évolution néonatale des taux plasmatiques d'iodothyronines totales et libres, de cortisol, de glucose et d'urée a été observée chez 8 agneaux témoins (poids de naissance $\geq$ $2,5 \mathrm{~kg}$ ) et 16 agneaux hypotrophiques (poids de naissance $<2,5 \mathrm{~kg}$ ) recevant des quantités limitées de colostrum au cours des 36 premières heures, puis nourris ad libitum.

Pendant la période de distribution de colostrum, la glycémie est faible chez tous les animaux puis augmente dès le début de l'alimentation ad libitum. Elle est significativement plus faible chez les agneaux hypotrophiques de la naissance à $36 \mathrm{~h}$.

L'urémie s'élève pendant la période de distribution de colostrum puis diminue chez tous les animaux. A la naissance, elle est significativement plus élevée chez les agneaux hypotrophiques.

Pendant toute la période expérimentale ( 20 jours), les taux plasmatiques de T4 totale, T4 libre, T3 totale et T3 libre sont fortement abaissés chez les agneaux hypotrophiques, sans altération de la valeur du rapport T3/T4 libre. Aucune différence significative n'apparaît pour la cortisolémie et la triiodothyroninémie inverse. De plus, les évolutions néonatales de tous les paramètres sanguins mesurés sont parallèles chez les deux groupes d'animaux; ceci suggère que les réponses métaboliques et hormonales à l'état nutritionnel et à la naissance sont qualitativement les mêmes chez les agneaux hypotrophiques et témoins, en dépit de l'hypoglycémie et du déficit en hormones iodées circulantes mis en évidence chez les premiers.

En accord avec l'hypoglycémie et l'hyperurémie observées à la naissance chez l'agneau hypotrophique, la taille de la portée enregistrée dans les deux lots expérimentaux, et les travaux antérieurs du laboratoire, ce déficit hormonal pourrait être induit par une insuffisance placentaire.

\section{Références}

ALEXANDER G., 1974. Birth weight of lambs : influences and consequences. In Size at birth, CIBA foundation Symp., Elsevier, Amsterdam, 215-246.

ALEXANDER G., 1978. Factors regulating the growth of the placenta : with comments on the relationship between placental weight and fetal weight. In Abnormal fetal growth: Biological bases and consequences, Ed. NAFTOLIN, Ababon Verlags-Gesellschaft, Berlin, 149-164.

BERBIGIER P., DUSSUEL A., 1977. Etude des cinétiques de temperature et du confort thermique du porcelet pendant I'heure suivant la mise bas. In Energétique et thermique de l'Homme dans son environnement (Rencontre SFT, Strasbourg, 16, 17, 18 mai 1977).

BERGMEYER H. U., BERNT E., SCHMIDT F., STORK H., 1974. Glucose : determination with hexokinase and glucose-6-phosphate-dehydrogenase. In Methods of enzymatique analysis, vol. 3. Acad. Press, New York, 1196-1201.

BROCK-JACOBSEN B., ANDERSEN H. J., PETERSEIN B., DIGE-PETERSEIN H., HUMMER L., 1977. Serum levels of thyrotropin, thyroxine, and triiodothyronine in fullterm, small for gestational age and preterm newborn babies. Acta Paediatr. Scand., 66, 681-687.

BROCK-JACOBSEN B., PETERSEIN B., ANDERSEN H. J., HUMMER L., 1979. Serum concentrations of thyroxine-binding globulin, prealbumin and albumin in healthy full-term, small for gestational age and preterm newborn infants. Acta Paediatr. Scand., 68, 49-55.

CABELLO G., 1983. Endocrine reactivity (T3, T4, cortisol) during cold exposure in preterm and full term lambs. Biol. Neonate, 44, 224-233. 
CABELLO G., LEVIEUX D., 1980. Neonatal changes in the concentrations of thyrotropin, triiodothyronine, thyroxine and cortisol in the plasma of pre-term and full-term lambs. $J$. develop. Physiol., 2, 59-69.

CABELLO G., LEVIEUX D., 1981. Hormonal status in the newborn lamb (cortisol, T3, T4). Relationships to the birth weight and the length of gestation : effect of the litter size. Biol. Neonate, 39, 208-216.

CABELLO G., LEVIEUX D., GIRARDEAU J. P., 1984. Influence des hormones thyroïdiennes sur l'apparition des diarrhées néonatales chez le Ruminant. In les colloques de I'INSERM : La diarrhee du jeune, Ed. INSERM, Paris, 61-72.

CABELLO G., LEVIEUX D., GIRARDEAU J. P., LEFAIVRE J., 1983. Intestinal K99 + Escherichia coli adhesion and absorption of colostral $\operatorname{lgG}_{1}$ in the newborn lamb : effect of fetal infusion of thyroid hormones. Res. vet. Sci., 35, 242-244.

CUNNINGHAM M. D., HOLLINGSWORTH D. R., BELIN R. P., 1980. Impaired surfactant production in cretin lambs. Obstet. Gynecol., 4, 439.

DUSSAULT J. H., MORISSETTE J., LABERGE C., 1979. Blood thyroxine concentration is lower in low birth-weight infants. Clin. Chem., 12, 2047-2049.

ERENBERG A., 1978. The effect of perinatal factor on cord thyroxine concentration. Early Hum. Develop., 213, 283-289.

ERENBERG A., RHODES M. L., WEINSTEIN M. M., KENNEDY R. L., 1979. The effect of fetal thyroidectomy on ovine fetal lung maturation. Pediatr. Res., 13, 230-235.

HOPKINS P. S., THORBURN G. D., 1972. The effects of fetal thyroidectomy on the development of the ovine fetus. J. Endocr., 54, 55-56.

HOUSSIN Y., BRELURUT A., 1980. Mortalité avant sevrage d'agneaux de différents génotypes dans un troupeau en conduite intensive. Bull. Techn. C.R.Z.V. Theix, 40, 5-12.

HOUSSIN Y., DAVICCO M. J., 1979. Influence of birthweight on the digestibility of a milk-replacer in newborn lambs. Ann. Rech. vet., 10, 419-421.

KOLDOVSKY O., KRULICK L., TENORE A., JUMAWAN J., HOROWITZ C., LAU H., 1980. Effect of triiodothyronine injection on levels of triiodothyronine and thyroid-stimulating hormone in sera and milk of lactating rats and in sera of their sucklings; precocious development of jejunal-dissacharidases in the sucklings. Biol. Neonate, 37, 103-108.

MOORE J. J., SAX S. M., 1965. A revised automated procedure for urea nitrogen. Clin. chim. Acta, 11, 475-476.

MWOSU U. C., ANDAY E. K., BOLOGNESE R. J., BONGIOVANNI A. M., DELIVORIA-PAPADOPOULOS M., 1980. Effect of in utero intravenous administration of thyroxine and other hormones on the lung fluid lecithin/sphyngomyelin ratio in the fetal lamb. Am. J. Obstet. Gynecol., 188, 459-460.

SAKAGUCHI M., SUZUKI S., NAGASHIMA K., SHIMANO S., UCHIDA S., KUROUME T., 1983. Longitudinal study of free thyroxine in low-birth-weight infants by paper disk method. $J$. Pediatr., 103, 793-796.

SHUBBER A. H., DOXEY D. L., BLACK W. J. M., FITZSIMONS J., 1979. Colostrum production by ewes and the amounts ingested by lambs. Res. vet. Sci., 27, 280-282.

STBRAK V., MACHO L., SKULTETYOVA M., MICHALICKOVA J., 1978. Thyroid activity in early weaned and suckling infants and their lactating mothers. Endocrinol. exper., 12, 103-107.

THERIEZ M., TISSIER M., MOLENAT G., BRELURUT A., BRUN J. P., DACHEUX F., 1976. Productivité comparée de deux troupeaux de brebis Limousines et Romanov $\times$ Limousines en conduite intensive. In 27e Réun. annu. F.E.Z., G43, 551, 1-6.

UHRMANN S., MARK K. H., MAISELS M. J., FRIEDMAN Z., MURRAY F., KULIN H. E., KAPLAN M., UTIGER R., 1978. Thyroid function in the preterm infant : a longitudinal assessment. J. Pediatr., 92, 968-973.

WRUTNIAK C., 1985. Mise en évidence d'anomalies de la fonction thyrö̈dienne néonatale chez l'agneau hypotrophique. Origine et conséquences physiologiques. Th. $3^{\text {e }}$ cycle, Univ. Clermont-Ferrand.

WRUTNIAK C., CABELLO G., 1983. Changes in the concentration of thyroxine in the plasma of rat fetuses during late gestation : influence of ligation of the maternal uterine vein and artery. J. Endocr., 99, 233-238. 
WRUTNIAK C., CABELLO G., 1985. Endocrine activity in preterm and full-term lambs: 1. Adrenal response to synacthen. 2. Thyroid response to ovine TSH or TRH. Biol. Neonate, 47, 280-287.

WRUTNIAK C., CABELLO G., 1986. Influence of hypothyroidism on the lipolytic activity of norepinephrine in the newborn lamb. J. Endocr., 108, 451-454.

WRUTNIAK C., CABELLO G., 1987a. Effects of food restriction on cortisol, TSH and iodothyronine concentrations in the plasma of the newborn lamb. Reprod. Nutr. Dévelop., 27. $721-732$.

WRUTNIAK C., CABELLO G., 1987b. Neonatal thyroid function in the hypotrophic lamb. In Int. Symp. on Fetal and neonatal development, 2nd-7th August - Oxford (In press).

WRUTNIAK C., CABELLO G., BOSC M., 1985. Plasma free and total iodothyronines levels in hypophysectomized and intact lamb foetuses during the last third of gestation. Acta endocrinol., 110, 388-394.

YEH K. Y., MOOG F., 1975. Development of the small intestine in the hypophysectomized rat. II. Influence of cortisone, thyroxine, growth hormone and prolactin. Develop. Biol., 47. 173-184.

YEH K. Y., MOOG F., 1979. Pinocytosis persists in the ileum of hypophysectomized rats unless cloture is induced by thyroxine or cortisol. Develop. Biol., 69, 159. 